\title{
DEMOCRATIC SPACE: \\ The Ecstatic Geography of Walt Whitman \\ and Frank Lloyd Wright
}

\author{
JOHN ROCHE
}

The map speaks across the barriers of language; . . .

A map invites attention alike synoptically and analytically.

-Carl Sauer, "The Education of a Geographer"

WALT WHITMAN Is our great poet of geography-a fact readily apparent to any of his countrymen as soon as they read him. Whitman was an augur, but of a discrete, American type, absorbed ecstatically in considerations of spatial form even as contemporary Europe was either attuned to the approach of the temporal shock waves of intellectual and political revolution, or hearing, with Arnold, the "long, withdrawing roar" of a secure past.

Whitman could also look back. He was among the first historians of the city of Brooklyn, author of Brooklyniana. And he certainly spoke of the future in his familiar prophetic mode. But Walt, as an American, was comfortable with space, which represented to him, as to Jefferson or Boone, Greeley or Benton, both a divine gift and a "safety valve"1 for alleviating poverty and political instability.

Though Whitman usually remained ensconced in the insular space of Manhattan, or at other points along the continent's easternmost edge, he yet provided the American people with their first articulate mental map. In Leaves of Grass, the vectors all point westwards, as though the continent were a tilted billiards table. Yet, paradoxically, the image of Mannahatta is superimposed over the whole of this non-Euclidean and defiantly subjective map. By "Mannahatta," an Algonquin term, Whitman refers to a united and transfigured Manhattan-Brooklyn. Mannahatta is the idiosyncratic city of Whitman's experience, the ex-reporter's record of an increasingly energetic and cosmopolitan Eastern city. But it is, simultaneously, the type for the democratic cities, the New Mannahattas, which would emerge in the Western, "dominion-heart of America."2 These would grow more easily from their aboriginal ground, he believed, than had their predecessor; more easily admitting that direct interaction between man and nature, as between man and man, which Whitman longed for in spite of his enjoyment of the "Broadway Pageant." 
Frank Lloyd Wright, too, "was born an American / child of the ground and space, welcoming spaciousness as a modern human need," 3 as he himself said in 1936. Wright as a native Midwesterner was especially situated to perceive and welcome that spaciousness. Despite childhood stays in Massachusetts and Rhode Island, he returned frequently, and by his eleventh birthday, permanently, to his Wisconsin birthplace. Speaking of this move, Wright said that, "fate took me out to the prairies of the United States of AmericaUsonia let us say-and there in the tall grass I grew up ..."4

This idyllic scene is not so different from Whitman's descriptions of his own boyhood-Paumanok even had "the spreading Hempstead plains, then (1830-40) quite prairie-like"5 - yet Wright's experience is of an even vaster space. Both men shared a Westward tropism, but Wright lacked the antipodal attraction which Whitman felt for the East, especially for the New York islands. ${ }^{6}$

Wright's imagined city, Broadacre City, was grounded therefore in the physical and cultural terrain of the Midwest. Though attempting, like Whitman, to set a pattern for a new and more democratic city for all America, Wright rejected the Eastern model whose elements Whitman had, in large part, incorporated as he looked towards the West and the future. Where Whitman sensed exuberance and egalitarian fraternity, Wright saw (a halfcentury later) congestion and stratification. Wright was unapologetic in claiming that "America begins west of Buffalo. The greatest and most nearly beautiful city of our young nation is probably Chicago."7

If any discrete city contributed to the continuous city which Broadacres represents it is Chicago, which at the turn of the century taught the nation about modern office building, effective occupation of lakeside sites, and gracious suburban living. But it is the prairie itself which is the greatest contributor.

Broadacre City stretches out like that great shelf which extends westward from the Mississippi as far as the Rockies of the U.S. and Canada, and southward across Texas to the Sonora desert. A twelve square-foot scale model is all that was "built," and that represented only four square miles of this vast city. To locate Broadacres one needs a continental map, for it is intended to occupy at least all of the contiguous U.S.; and one needs maps that indicate the existing topography, rainfall, agricultural patterns, and ethnocultural concentrations, for Broadacre City is meant to be built with all of these conditions in mind. The population density, for instance, although always much closer to that of a small town or village than a typical city, would vary according to the terrain and its agricultural suitability. The unbroken line to the horizon that one sees from the prairie is the prime image representing Broadacres. It connects with the "Earth line" or "Horizontal" principle that Wright spoke of in connection to his building, a factor immediately recognizable in his early "Prairie-style" homes, and more subtly in later works like Taliesin West or the Marin County Center. Broadacres is to 
be, no less than the nation, connected architecturally and politically to the land.

Wright attempted an interweaving here of contrasting American ideals. $\mathrm{He}$ introduced extreme privacy by granting to each family a house of their own on a minimum of two "broad acres" of good land, yet made use of the most up-to-date innovations in transportation and communications-from the automobile and radio in the thirties, to the helicopter in his fifties revision - to encourage community. $\mathrm{He}$, in fact, was anticipating the "hub-less" cities made possible for the eighties and nineties by the computer revolution, although he would have strongly disagreed with the economic stratification and cultural poverty prevailing in our day, as he did of the ugly, sprawling suburbs of the post-war period which parodied his planning vision even as their "ranch houses" debased his prairie-and-Usonian styles in home design.

For Broadacres is not merely an exercise in massive urban planning, it is fundamentally a radical vision for America. Wright proposes the expropriation and free redistribution of land on a continental scale. ${ }^{8} \mathrm{He}$ proposes returning government and culture to the people by making the individual county the seat for most political and economic decisions, as well as the center for education and the arts. ${ }^{9} \mathrm{He}$ proposes, finally, to combine urban and rural living in an esthetic manner that does the least possible harm to the people or to the land; for example, by streamlining factories, regulating pollution, emphasizing landscaping, allowing wilderness preservation, and so on.

\section{"Maps Yet Unmade"}

Any attempt to compare and contrast Mannahatta with Broadacre City must acknowledge the inherent difficulties of such a proposition. Both are unbuilt, but each differs in its degree of explicitness. Mannahatta is, above all, an ideal, but one upon whose pristine surface has been etched the topical and social features of New York City. As such it resembles the panoramic paintings and photographs of Whitman's contemporaries, as Peter Conrad relates:

The panoramas popular at the time are models of Whitman's all-embracing urban pantheism, his capacity to comprehend the city in a single omniscient survey. Burckhardt's panorama wrapped New York into a sectional circle and placed the viewer at its midpoint, while in $\mathrm{E}$. Porter Belden's you looked down on it, seeing it all at once like Whitman in "Mannahatta."10

The Western cities incorporate the same ideal, but are more sketchily drawn.

Broadacre City, on the other hand, as represented in its 1935 scale model, is deceptively detailed considering that Wright claimed, "Broadacre City does not represent in any way a proposed plan, a fixed formal arrangement ..."11 But this scale model was itself an outgrowth of twenty years of 
considerations and sketches, and the concept of Broadacres as presented in The Disappearing City of 1932 would undergo continuous revisions until its best known and most specific embodiment, The Living City, was published in 1958, near the end of Wright's life.

To varying degrees, nevertheless, in the cases of Mannahatta and Broadacres, an ideal is proposed, and yet that ideal is confused, in seemingly deliberate fashion, with a set of particulars - each is given a geography, not merely a geometry. The dangers of such an approach are evident, for no explicit model could possibly fit the diverse terrains, climates, and cultures of this capacious nation. In Whitman's case, one expects, correctly, that this quintessential poet of the particular (the cataloger of each "kelson of the creation,") ${ }^{12}$ will rapturously devote himself to the incidences of his own city, whose streets he celebrates.

To Whitman, in 1860, the extension of present marvels like paved streets and the innovative iron work and other technologies he had seen at New York's Crystal Palace exhibition into the heartland of the nation must have seemed prophecy indeed. New York and New England were inescapably the centers and the symbols of this technological revolution in America, and so it was not surprising that he would see the future in the East as well as in the frontier West, complementary contributors to a prosperous new nation egalitarian in art, manners, government, and economy. ${ }^{13}$

Yet, especially after the Civil War, when populating the new lands became a national priority and when the failures of the existing cities and their society became apparent, he focused more often on those "mighty inland cities yet unsurvey'd and unsuspected." 14 He saw in the West "Our Real Culmination" 15 as a nation, and wrote that, "In a few years the dominion-heart of America will be far inland, toward the West." 16 One wishes that he had been more detailed about these prophecies, but in his later prose pieces he drew some appealing portraits of the new communities where the citizens would reside, "millions of comfortable city homestead and moderate-sized farms, healthy and independent" 17 in neo-Jeffersonian sufficiency.

Whitman, however, acknowledged the limitations of all his projections, as he acknowledged those of his poetry: "Then ... we have to say there can be no complete or epical presentation of democracy in the aggregate, or anything like it, at this day, ... . Thus we presume to write, as it were, upon things that exist not, and travel by maps yet unmade and a blank." 18 Though Whitman was relatively comfortable with this pregnant uncertainty, he was a poet of life-as-lived, and so he included on his maps the makings and wanderings of the ordinary people he encountered.

Wright, too, was aware of the incomplete and essentially incompletable order of his Broadacres task, though as an architect it was his duty to delineate and not just celebrate the new city. The new sketches that he included a year before his death, while not significantly altering the Midwest-like landscape of the 1930s model, did introduce several buildings from his later 
repertoire, including those meant for California or Southwestern sites. ${ }^{19}$

It is interesting that one of the Whitman passages which Wright chose for his 1938 Architectural Forum issue also illustrated the theme of the everconstructive imagination: "Say on-sayers! Dig, model, pile up the words of the earth. Work on age after age-nothing is to be lost; it may have to wait long, but it will certainly come in use; when the materials are all prepared, the architects shall appear." 20 The idea that artistic and social creations, of which Mannahatta and Broadacres are two, must be ongoing constructs is an evolutionary one, in the wider sense. Whitman and Wright were familiar with compatible concepts, such as, for example, Jefferson's belief in a revolution repeated each generation, Fichte's ever-unfinished temple of philosophy, and Emerson's dictum: "neither can any artist entirely exclude the conventional, the local, the perishable from his book . . . Each age, it is found, must write its own books; or rather, each generation for the next succeeding."21

In the geographical analogue, based on a narrower sense of "local" than Emerson fully intended, ${ }^{22}$ it is the topos or site which provides the counterbalance to the general space which, for these artists, is usually America. The necessity of localizing their ideal cities, of subtracting ous from "utopia," was as clear to each man as the necessity of rooting a poem in topical occurrences was to Whitman ("Crossing Brooklyn Ferry"), or orienting a house to its ground ("Fallingwater") was to Wright.

Geography is important to Whitman and Wright, then, both as continental focus and as local study. Geography, of course, has many definitions, and as a discipline many specializations. Foremost, for our concerns, is the phenomenology of space, the area of Perceptual Geography. A second is Cultural Geography, or what Carl Sauer called "Human Geography," especially as it relates to the "localization of ways of living,"23 and including Urban Geography insofar as that deals with the city's relationship to its land. Finally, Geography is of interest in its concern with mapping, as Whitman and Wright were both engaged in a search for analogues to their and their nation's experience. The present concern will be, primarily, with Perceptual Geography.

\section{Ecstatic Geography}

For geographers, architects, and psychologists, the study of the ways in which we perceive space has become, in recent years, an enormously important undertaking, spurred on by the failure of the housing projects of the 1960s, the emergence of a strong Environmental movement in the 1970s, and the complexities surrounding attempts at urban revitalization in this decade. For geographers, especially, the notion of a "mental map," or subjective apprehension of space, first introduced by Charles Trowbridge early in the century, is quite useful. It has since been used not only by geographers like Peter 
Gould and Yi Fu Tuan, but by figures from various disciplines, like architect and urban planner Kevin Lynch and psychologist James Hillman.

It was remarked earlier how Whitman and Wright both conceived of American space as an immense vastness, yet neither reacted to vastness with the inescapable dread one finds, say, in Moby Dick. ${ }^{24}$ Instead, both men are agoraphiles, reveling in the experience of inexhaustible space as a renewable source of personal and artistic energy, impervious to time's ephemerality. (In this, they stay close to the ancient sense of space as a verb: "to increase," "to hope," or "to prosper." $)^{25}$ References to this revivifying experience of space permeate Leaves of Grass; a particularly intricate example occurs in "To the Sun-Set Breeze," where that breeze entering his sickroom has a recuperative effect and is envisioned by the poet as first, a "messenger-magical strange bringer to body and spirit of me," and second, as North American space: "I feel the sky, the prairies vast-I feel the mighty northern lakes, / I feel the ocean and the forest-somehow I feel the globe itself swift-swimming in space. . .."26 Like the coolness that comes in through his window, space here is the very thing denied the sick man-which is of course why it is a fitting representation of freedom and, moreover, a fitting analogue to that other lake, the breath of life.

Space is, in the poem, directly related to a "dialectic of outside and inside"; the phrase is from Gaston Bachelard's brilliant phenomenological romp, The Poetics of Space. ${ }^{27}$ Inside, Bachelard observes, is usually associated in the imagination with the concrete, as outside with the vast, but these are not absolute opposites, ${ }^{28}$ as they are not in "To the Sun-Set Breeze." Rather, the space within the room becomes continuous with that beyond it, as in Whitman's perception where it becomes equally filled by the "universal concrete's distillation," 29 or filled (in Bachelard's psychological, not metaphysical, view) by a common "immensity." 30 As Bachelard writes: ". . . it is through their 'immensity' that these two kinds of space-the space of intimacy and world space-blend. When human solitude deepens, then the two immensities touch and become identical." ${ }^{31}$ This moment of deepening solitude, this "inner state that is so unlike any other," 32 is identified by Bachelard with the creative "reverie," an associational condition which proceeds by a "dialectic of superposition." ${ }^{33}$ Reverie does not seek to resolve or synthesize the generated images, but lets these apparitions "reverberate" with multiple meanings. ${ }^{34}$ This experience, which Bachelard also depicts oxymoronically as one of "intimate immensity," 35 is similar to what Whitman referred to as "ecstasy," a state of happiness ${ }^{36}$ giving vent to poetry or song which is linked, as in the following short poem, to a contemplation of particulars:

Beginning my studies the first step pleas'd me so much,

The mere fact of consciousness, these forms, the power of motion,

The least insect or animal, the sense, eyesight, love,

The first step I say awed me and pleas'd me so much,

I have hardly gone and hardly wish'd to go any further,

But stop and loiter all the time to sing it in ecstatic songs. ${ }^{37}$ 
As in reverie, there is no urge to go beyond the first step of apprehension to the following analytic stage; the narrator is content to take in natural forms and to utter, in its original sense, corresponding words. ${ }^{38}$

Recognizable in the previous sentence is a description of Whitman's poetic method, which is based on naming as a holy act: "Names are magicOne word can pour such a flood through the soul." 39 Place names are the most common of such utterances in Whitman's poetry.

The parallels between the creative act and religious or mystical ecstasy have often been remarked on, as in works by Otto Rank and Rudolf Otto. ${ }^{40}$ Whitman makes this connection frequently, recognizing the interrelation of poetic, spiritual and even erotic stimuli (or "excitations" in Otto's term), within the shared space of his own mind, as well as the "essential correspondence" 41 of that inner space ${ }^{42}$ to the extended landscape. An example occurs as he discusses his ideal society:

I say the question of Nature, largely consider'd, involves the questions of the esthetic, the emotional, and the religious - and involves happiness. A fitly born and bred race, growing up in right conditions of out-door as much as in-door harmony, activity and development, would probably, from and in those conditions, find it enough merely to live- and would, in their relations to the sky, air, water, trees, \&c., and to the countless common shows, and in the fact of life itself, discover and achieve happiness - with Being suffused night and day by wholesome extasy, surpassing all ...43

This correspondence between Whitman's images of landscape and his psychic states Gay Wilson Allen called "panpsychism," 44 and he found in it "ideas of transmission and identification resembling the imitative magic of animistic religions." 45 Allen himself is most interested in topographical images as symbols of Whitman's interior processes, as they certainly can be read. But it is equally important to dwell on the power, for Whitman, of geographic space to initiate or catalyze events in consciousness, and also to define a national political and esthetic identity.

In the case of those central events or ecstasies-no longer the special province of mad monks or artists, but as common as daydreams in Whitman's democratic citizenry-the landscape provides both a coherent matrix for metaphorical representations and a major type of excitation or trigger for the experiences themselves. The first instance, the geographical image as metaphor, is quite prominent in Leaves of Grass - even in the title-and has received sufficient critical attention so as to hardly necessitate illustration, but a passage from the opening section of "Salut Au Monde!" renders Whitman's method particularly transparent:

What widens within you Walt Whitman?

What waves and soils exuding?

What climes? what persons and cities are here ${ }^{46}$ 
Moving on to Whitman's proclivity for spatial metaphors of psychological states, guideposts may be found in Bachelard's Poetics of Space and Yi Fu Tuan's Topophilia, ${ }^{47}$ which separately explain how spatial apprehension, with its close relationship to our awareness of the structure of our bodies, is central to most ways of representing the fact of ourselves in the world. It is, for example, nearly impossible in English to speak of mental states without using spatial metaphors. We speak of "inner" states and "areas" of behavior. Our words for the soul are derived from the breath, with its inward-andoutward pattern. Greek- or Latin-based words like "proclivity," "derangement," and even "emotion" have spatial reference. The term "ecstasy," which is central to Whitman's imaginal and geographical concerns, means literally "to put out of place" or "to stand outside."48 Ecstasy, or "extasy," as Whitman also spelled it, is used by him to indicate anything from simple exuberance to an overwhelming experience not unlike that reported by mystics, although Whitman's democratic vantage would see both as degrees of an identical experience.

A report of a spiritual "transformation" by the English writer Edward Carpenter, ${ }^{49}$ a friend and admirer of Whitman, emphasizes the spatial nature-the feeling of extending outwards into space or of "standing outside" one's body-often accompanying mystical states:

Or again a strange sense of Extension comes on me-and of presence in distant space and time. Mine is an endless Life, unconquerable, limitless in subtlety and expanse; and strange intimations that it is so come to me even in my tiny earth-cell-intimations of power inexhaustible, of knowledge mysterious and unbounded, and of far presence through all forms and ranges of being. ${ }^{50}$

Whitman's philosophy of "Personalism" demands that he maintain and expand his ego: his wisdom comes from "dilation," not from denial of self; from an equation of self with Self, not from self-sacrifice. As a poet Whitman seeks not to transcend the self, but to transcend such categories as self/notself, inner/outer, etc. He continually subverts expected dichotomies, affirming both body and psyche, granting the poet a political role, and adhering to cultural pluralism; these are not the ecstasies of a narcissist, but a possible transversing of the solipsistic minefield that, we are told by Freudian or Marxist analyses, ${ }^{51}$ underlies most poetics of the sublime.

It is not surprising, therefore, that he prefers those representations of ecstasy which emphasize space even as they transcend it. Neither is it surprising that he gives us many examples of ecstasy that are either directly triggered by awe of panoramic vistas and similar topophilic experiences, or indirectly aided by the sublimity of some landscape upon which love, battle, patriotic celebrations, or the excitement of the ferry ride induce a heightened state.

If questions remain as to why and how geographical images figure so prominently and seemingly easily as representations of Whitman's interior life, particularly in regard to such intensely felt and possibility-filled experi- 
ences, one might iterate the obvious yet impenetrable fact of American space as utterly new, discrete, and numinous:

A boundless field to fill! A new creation, with needed orbic works launch'd forth, to revolve in free and lawful circuits - to move, self-poised, through the ether, and shine like heaven's own suns! With such, and nothing less, we suggest that New World literature, fit to rise upon, cohere, and signalize in time, these States. ${ }^{52}$

Such is the promise of America's "momentous spaces." 53 They provide both the inspiration and the resources necessary for an unprecedented literature and government-the former represented by Whitman through a metaphor of galactic space, which indicates both the strangeness and the spiritualness that America derives from her setting.

Beyond the inescapability of American geography as perception, the above passage makes clear the uses to which Whitman puts spatial imagery on behalf of his program for a national esthetic which would, in turn, consolidate the democratic society and political union of the U.S. ${ }^{54}$ If the goal was to celebrate America's space, it was also necessary to celebrate its places and place-names.

Lacking the accrued significances of an ancient history, American sites must be discovered for the imagination. Although Irving, Cooper, and Longfellow had done the preliminary work of poetic founding for the Northeast by the time Whitman entered the scene, and Thoreau and Hawthorne were completing theirs, little but Paul Bunyan tales were available to imaginatively locate the West (Beadle Dime-Novels had not even begun ${ }^{55}$ ). Whitman's emphasis on place-names and topography is partially to this end, although as an Easterner it is not surprising that his specific focusings on the West are few relative to his references to New York and Long Island geography and, until his 1879 trip to Denver, less detailed.

What he lacks in number of specific references to Western sites, however, Whitman compensates for in his frequent references to American space as a unified, continental presence, and to that vastness as a unifying force in the nation's life. Whitman sought always to correct the amorphic vision that fragments the continental field into competing regions, each with an opposed perspective-in this he resembles his hero, Lincoln. An American must not be defined by space as a boundary, but by the common experience of inhabiting an infinity. They wanted us to stretch.

\section{Space Unbound}

Among the Whitman passages which Frank Lloyd Wright chose for his special issue of the Architectural Forum in January 1938 can be found the following lines: "I inhale great draughts of space. / The East and the West are mine, and the North and the South are mine ..."56 Wright's Autobiography opens with the following scene: 
Light blanket of snow fresh-fallen over sloping fields, gleaming in the morning sun. Clusters of pod-topped weeds woven of bronze here and there sprinkling the spotless expanse of white. Dark sprays of slender metallic straight lines, tipped with quivering dots. Pattern to the eye of the sun, as the sun spread delicate network of more pattern in blue shadows on the white beneath. ${ }^{57}$

Between the continental expanse and epic tone of the first passage and the undulating, broken expanse of the lyrical second, there is little in common besides an attention to space. The first is sublime, while the second is beautiful. The first communicates power-the power of untamed spaces, the power of men who become giants by absorbing some of the vastness they live within, and the power of the first poem elastic enough to swallow those nearly infinite spaces that only chaos, it was previously thought, could hold. Yet the second passage is an eclogue of early winter, telling of a localized and humanized landscape -a "place" or "piece of the whole environment that has been claimed by feelings," as Alan Gussow defines it. ${ }^{58}$

One cannot ascribe any contrasting characteristics to Whitman and to Wright based on these two isolated passages, of course. Wright clearly admired the titan in Whitman, which is one reason he selected the above quote. There are many selections from Whitman which consider space as discrete and tame places - "Sounds of the Winter," 59 for instance, could be placed alongside Wright's descriptive narrative. And even though Whitman as an epic poet is obliged to present the American continent in panorama whereas Wright as an architect must necessarily attend to the individual site, it is also the case that Whitman includes the lyrical and the individual, as Wright frequently shifts to an apprehension of expansive space in his architectural theorizings and conceptions of Broadacres.

Yet, the two passages do reintroduce a "dialectic of outside and inside" in respect to continuous, usually continental space versus discrete, localized space-a polarity which Wright incorporated, as would become evident in his concept of the "Earth Line." 60 The passages, moreover, are evidences of Wright's preoccupation with geography-that he is a "child of space," or as Mumford referred to him, a "poet of space,"61 and that he is, like Whitman, receptive to its ecstasies.

The first book of. Wright's Autobiography is interspersed with boyhood memories of the Taliesin valley, with its "sloping fields," "wooded hills," and "wild Wisconsin pastures" in whose "marvelous book-of-books, NatureExperience" the young Wright was discovering a corresponding "inner experience for what he heard or saw."62

The opening passage, in fact, presents Midwestern nature as seen through an inner, geometrically cognizant eye more sophisticated than the nine-year-old Frank can be expected to possess. Pattern is quite visible in the bronze-"woven" weeds and the "delicate network" of shadows, as the author envisions a landscape composed of "metallic straight lines," "clusters," and "dots" (one might almost have the elements of a Louis Sullivan façade instead of a landscape!). 
A later passage also has a split focus, but is more attendant to the boy's awareness, with its ecstatic fusion of place, eros, and the infinite:

Sometimes . . . he would get out of bed, sweaty jeans pulled on, rolled above his knees, and barefoot and bareheaded slowly climb the path up the hill behind the house. Climb to the long, quiet ride that ran to the north high in the moonlight, ornamented here and there with scattered hazel-brush and trees. Climbing to wander, look forward and imagine, enjoy waking dreams in a high place. ...

On either side of the ridge lay fertile valleys luminously bathed and gentled by the moon. The different trees all made their special kinds of pattern when the moon shone on them and their favorite deep-dark silhouettes when it shone against them. . . Broad, shallow mists, distilled from heavy dews, ... . were lying free over the tree-tops in long, thin, flat ribands. ... The ancient element of moisture seemed to prevail there as a kind of light flooding over all. The deep shadows held mysteries alluring and friendly to the boy. No haste now. ${ }^{63}$

Wright is known as the leading architect of the "Prairie Style," and the majority of those early houses were set in the Oak Park outskirts of Chicago. Today a suburban village, in the 1890 s Oak Park fronted the prairie. Wright's own Home-and-Studio, a precursor of that style, is situated so that the design studio faced the edge of town where, a couple of hundred yards off, cattle grazed; the home more sociably flanked an existing house, and faced several houses Wright had recently built. There is a third direction apparent here, as in, to varying degrees, all of Wright's houses: an interior, hearth-centered space whose reflective windows allow in light but not strangers' gazes, and whose domestic comforts provide shelter from that same prairie which Wright's imagination found indispensable. Taliesin, Wright's next home, looks over a river valley adjacent to Wisconsin's prairies, so it is also a place shielded from the awful sameness of the prairie - that "scene of desolate stillness ... with unbroken horizon, under a cloudless sky,"64 as Schopenhauer envisions the sublime. Wright, in abandoning his practice and family in the suburb of Oak Park almost as impetuously as his fellow Midwesterner, Sherwood Anderson, left his family and conventional job to become a writer, did not head for the interior of some metropolis. But neither did he search out the forbidding wilds, or even the cultivated-yet-uninterrupted prairies. Instead, he settled, after a tour of Europe, in the Wisconsin vale that was scene to his childhood idylls.

Inhabiting Taliesin, Wright, the advocate of a prairie architecture, might resemble Whitman, the poet of the open road, whose peripatetics were limited, aside from one trip to New Orleans, one to Canada, and one to the West, to an ellipse whose points include Boston, New York, Camden, Washington, D.C., and Long Island. Taliesin was a garden in the original sense of enclosed, sacralized space. It was a place he could work with few distractions, and also a refuge for himself and his lover, Mamah Borthwick Cheney, against the unrelenting voices of the scandal sheets. Mannahatta, as an island, is symbolically a garden in this sense for Whitman, too. Whitman found his safety within the anonymity of the crowds that strolled down Fifth Avenue, or rode the trolleys. 
The dialectics of outside and inside, however, are often beyond our ken as they relate to the creative choices of a particular artist, as are the needs which go into those choices. Whitman seems to have needed Mannahatta as a place in his poem more than he needed it as a place to remain in. Wright used Taliesin as a workshop and occasional retreat, but his place as an architect was out supervising construction wherever and whenever there was a project. It is possible that the tragic fire of 1914 , in which a madman murdered Mamah and her children, and two subsequent fires at Taliesin, deprived it of some of its talismanic power and womb-like serenity for Wright. That memento mori which appeared on seventeenth-century landscape paintings would be appropriate in regard to Taliesin: "Et in Arcadia Ego," or, "I (Death) also am in Arcadia."65

Perhaps a reduction in the symbolic safety of Taliesin's discrete space was a factor in Wright's construction of Taliesin West in Arizona, where he would live for decades with his last wife, Olgivanna, although other factors such as his growing enchantment with the Southwest and a health problem which demanded a warm climate were primary. ${ }^{66} \mathrm{In}$ any case it is interesting to consider this move-occurring shortly after his Broadacre model-as part of a significant transformation in his artistic career. The journey from the discrete and humanized spaces of Wisconsin to the floor of a vast desert was a step in the larger journey Wright took in his "second" career towards an architecture evolving into radically innovative forms which were, nevertheless, more and more finely attuned to the nature of materials and topographies.

Robert Twombly discusses the Taliesin West site as an expression of emotional reorientation, and, one could add, an affirmation of unlimited space as the American reality:

This close interrelationship (between building and site) had contributed to a fortresslike atmosphere at Spring Green, but in the desert worked in completely different ways. Alone with his mistress in 1911, Wright had valued privacy, protection from hostile outsiders, and a sense of shelter above all. Happily married for a decade by 1938 with commissions coming and new ideas developing rapidly, he now faced the world confidently, without fear. Taliesin East achieved its security and its architectural success from its commanding hill-top position, overlooking the valley and controlling its own access routes like the castle of a feudal baron. Taliesin West, on the other hand, sits alone and unprotected on the desert floor, dominated by the mountains to which it pays tribute, exposed on all sides like the lonely home of a pioneer. ... But the sand and the canvas and the water suggested a certain impermanence, as if Wright had learned that the strongest fortress guaranteed nothing. Only the looming mountain was certain of immortality. ${ }^{67}$

Wright had, in several senses, come to his bedrock, and found it was sand. Heraclitean as he had always, at heart, been, 68 Wright was becoming more resolvedly aware of "The Inexorable Law of Change." 69 And he was realizing, in an architecture newly based on the shifting of elemental materials and forms, ${ }^{70}$ the temporal and spatial freedom he had always sought: "In the realm of his own imagination come forms found only in freedom of spirit. Space outflowing instead of static containment. Liberation a fulfillment. Ar- 
chitecture no longer any kind of fortification but generously spacious and plastic."71

This statement was written by Wright in the 1950s, but as early as the thirties Wright had promulgated a socio-esthetic based on "THE NEW. STANDARD OF SPACE MEASUREMENT,"72 stressing mobility, centrifugal directionality, and horizontality in emulation of the "democratic" nomad versus the fearful cavedweller. In this parable Wright distinguished the imaginative, adventurous, and innovative in man from the obedient, laboring, and bourgeois; the latter qualities he associated with repressive government and repressed society, and with the city, an overcrowded "WHIRLING VORTEX"73 constricting individuality.

Wright was forced to admit at the time that the two aspects of humanity have blended and fought throughout history, and that each aspect is found in any individual. Even so, the urge to fortify seems to have been stronger in himself than Wright might then have realized. Luckily, he and his architecture were able to subsume this need into the improvisatory and less restrictive forms of shelter required by new climates and ways of life, gaining in the process that mobility which was second nature to Whitman and his poetry.

Wright was, thus, akin to Whitman in his sensitivity to the presence and importance of American spaciousness, and was equally agoraphilic. Both men valued centrifugality; for Whitman it was indicative of the emergence of words from the mouth of the poet, of the unfolding of the "kosmos" in evolution, of the soul's voyage, and of sympathy as the principle of extension of self.

Wright embraced, for the most part, these insights of Whitman, but with two differences. First, Wright applied this centrifugal necessity to his solution for the congested city in a far more drastic way than the crowd-energized Whitman would have approved. And, second, Wright was less apt to view the spread of democracy as equivalent to the spread of America's boundaries, though growing older Whitman had himself grown less chauvinistic.

The American continent is not the only space which Whitman's imagination gauges, of course, but this great envelope is the "stubborn fact," in Whitehead's terminology, "which at once limits and provides opportunity for the actual occasion"74 of Leaves of Grass. In the same way, as Wright's European commentators unanimously point out, the Broadacres model could never be applied on the older Continent, which simply lacks the Lebensraum such an experiment requires. Yet such an inexhaustible space, in our time, when even the solar system is becoming man's junkyard, seems all too finite. But North American space was also, for Whitman and Wright, a symbolic work space where necessary creations on whatever level-esthetic, political, spiritual-could occur, and for this there's still room: 
Others take finish, but the Republic is ever constructive and ever keeps vista, ...

O America because you build for mankind I build for you,

$O$ well-beloved stone-cutters, I lead them who plan with decision and science,

Lead the present with friendly hand toward the future. ${ }^{75}$

\section{Michigan State University}

\section{NOTES}

1 As Henry Nash Smith has observed in Virgin Land (New York:Vintage, 1970); see ch. 20, also chs. 11 and 15.

2 Walt Whitman, "Democratic Vistias," Prose Works 1892, ed. Floyd Stovall (New York: New York University Press, 1968), 2:384.

3 Frank Lloyd Wright, from Architect's fournal, London: July 16-August 6, 1936, included in Wright, An American Architecture, ed. Edgar Kaufmann, Jr. (New York: Bramhall House, 1955), 61.

4 Wright, The Master Architect: Conversations with Frank Lloyd Wright, ed. Justin Meehan (New York: Wiley, 1984), 241.

5 Whitman, "Specimen Days," $P W, 1: 11$.

6 It is worth keeping in mind that Whitman is foremost an islander and his earliest experience of expansive space must have come, as for Melville's Nantucketers, from the sea. See Joan Berbrich, Three Voices from Paumanok (Port Washington: Friedman, 1969), 170-195. As illustration, see "From Montauk Point," Leaves of Grass: Comprehensive Reader's Edition, ed. Harold W. Blodgett and Sculley Bradley (New York: Norton, 1965), 508. (References are to this edition unless otherwise specified.)

7 Wright, London Lecture no. 3 (1939), The Future of Architecture (New York: Horizon, 1953), 282. On p. 289, Wright answers a questioner as to why Chicago is the most beautiful city:

First of all because it has a generous park system, the greatest on earth . . . Chicago seems to be the only great city in our States to have discovered its own waterfront ... Chicago takes pride in building things in a big substantial broad way ... even gangsters.

The first two points here are remarkably parallel to planning trends in the 1880 s, even though the final comment betrays the passage's date.

8 Wright cites Henry George as his model here, yet opposes George's Single Tax, favoring instead some system of just compensation for the expropriated; Wright appears to be following Silvio Gesell on this point.

9 County Seat: Surrounds small lake near eastern edge of model; County Architect's building \& crafts center on one side of lake, government \& corporate office buildings on other side; Arena with festival pole just north. Adjacent to Arena is a north-south strip of museums, zoo, aquarium, etc. East of Arena, secluded, are country club and sanitarium; County Building: Consolidates all governmental functions (public safety, legislative, judicial, administrative); Community Center; “. . . salient feature of every countryside development of the county, wherever the county seat might be ... Golf courses, race tracks, the zoo, aquarium, planetarium-all would be found at this general center. Good buildings grouped in architectural ensemble with botanical gardens, art museums, libraries, galleries, opera, etc." (Wright, The Living City [New York: Horizon, 1958], 174-176). 
10 The Art of the City: Views and Versions of New York (New York: Oxford University Press, 1984), 18.

11 Wright, cited by Lionel March, "An Architect in Search of Democracy: Broadacre City," Writings on Wright, ed. H. Allen Brooks (Cambridge: MIT Press, 1981), 204.

12 "Song of Myself" 5:95, Leaves, 33.

13 Despite the fact that many inventions in what John Kouwenhoven called the American "vernacular" occurred in the West as improvisations due to the lack of standard materials or procedures-see The Arts in Modern American Civilization (New York: Norton, 1948), also published as Made in America. For Whitman's reaction to the Crystal Palace, see Justin Kaplan, Walt Whitman: A Life (New York: Simon and Schuster, 1980), 179-183.

14 Whitman, "Thoughts" 2:26, Leaves, 494.

15 Whitman, $P W, 2: 539-540$.

16 "Vistas," $P W, 1: 384$.

17 “Our Real Culmination," $P W, 2: 539$.

18 "Vistas," $P W, 2: 389,391$.

19 See Robert C. Twombly, Frank Lloyd Wright: An Interpretive Biography (New York: Harper, 1973), 304-305. The drawings appear in many of Wright's books and anthologies, including The Living City, Writings and Buildings, and The Master Architect.

20 Whitman, "A Song of the Rolling Earth," 4: 121-126, 127-130, cited in Wright, "Broadacre City" insert to The Architectural Forum, January 1938.

21 "The American Scholar," Selections from Ralph Waldo Emerson, ed. Stephen E. Whicher (Boston: Houghton Mifflin, 1957), 67.

22 The term "local" in Emerson's passage implies the philosophical sense of "accidental" or "particular."

23 Carl Sauer, Land and Life (Berkeley: University of California Press, 1963), 358.

24 Melville frequently alludes to the treacherous sublimity of the vast oceans, as in the following passage: "Already we are boldly launched upon the deep; but soon we shall be lost in its unshored, harborless immensities." (Moby Dick [1851: Baltimore: Penguin, 1972], 227.) Olson, in Call Me Ishmael (San Francisco: City Lights, 1947), 11-13, observed that space in America "comes large here. Large and without mercy." And that Melville "had all space concentrated into the form of a whale called Moby Dick."

25 From Indo-European root spe, related to Sanskrit sphayati, "he increases," and Latin spes, "hope."-American Heritage Dictionary of Indo-European Roots, ed. Calvert Watkins (Boston: Houghton-Mifflin, 1985), and Origins, ed. Eric Partridge (New York: Greenwich, 1983).

26 Whitman, "To the Sun-Set Breeze" 8, 10-11, Leaves, 546.

27 Gaston Bachelard, The Poetics of Space, trans. Maria Jolas (1958; Boston: Beacon, 1964) title of ch. 9. Bachelard shares with Whitman and Wright an affinity to Coleridge and his German post-Kantian predecessors; see Neil Forsyth, "Gaston Bachelard's Theory of the Poetic Imagination: Psychoanalysis to Phenomenology," The Quest for Imagination: Essays in Twentieth-Century Aesthetic Criticism, ed. O. B. Hardison, Jr. (Cleveland: Case Western Reserve University Press, 1971), 225-253.

28 See Bachelard, 215.

29 Whitman, “To the Sun-Set Breeze" 15, Leaves, 546. 
30 Bachelard, 203.

31 Bachelard, 203.

32 Bachelard, 183.

33 Bachelard, On Poetic Imagination and Reverie: Selections, trans. Colette Gaudin (New York: Merrill, 1971), 8.

34 Bachelard, Imagination, 82-83.

35 Bachelard, Space, 183; see 202-203.

36 Whitman's "ecstasy" was always a condition associated with health and happiness - not at all the "derangement" (existanai) which it sometimes implies.

37 Whitman, "Beginning My Studies," Leaves, 9.

38 The word "utter," as "to direct outward."

39 Whitman, An American Primer (Boston: Small, 1904), 18; see 17, 19, 31-32. Wright is also fond of the magic of names: e.g., "Taliesin" (Welsh: "Shining Brow"), "Hollyhock," "Fallingwater."

40 See Otto Rank, Art and Artist (1932; New York: Agathon, 1968), 85-87, on the similarities and differences among the "aesthetic," "religious," and "erotic" experiences. Also see Rank, 291-293, and ch. 14; see Rudolph Otto, The Idea of the Holy (New York: Oxford University Press, 1958), 42-49.

41 Otto, 45.

42 See Gay Wilson Allen, "Walt Whitman's Inner Space," Papers on Language and Literature 5 (Supplement, Summer 1969), 7. Bachelard, in Imagination, 36, says of this connection: "In a general way, I believe that the psychology of aesthetic emotion would profit from studying the kinds of material reveries which precede contemplation. We dream before contemplating. Any landscape is an oneiric experience before becoming a conscious spectacle."

43 Whitman, "Vistas" $P W, 2: 416$.

44 Allen, "Inner Space," 10.

45 Allen, "Inner Space," 10.

46 Whitman, "Salut Au Monde!" 5-8, 11-16, 20-21, Leaves, 137-138.

47 Yi Fu Tuan, Topophilia (Englewood Cliffs: Prentice-Hall, 1974).

48 From Greek ex, "out" and histanai, "to cause to stand" (Webster's); Greek histanai, "to set, place" (American Heritage Dictionary).

49 Bucke included both Whitman and Carpenter in his examples of men who had attained to visionary states, in his book Cosmic Consciousness. Carpenter, by the way, was involved in Chicago Arts and Crafts Society activities at the same time Wright was, according to Peter I. Abernathy, in "Frank Lloyd Wright/Walt Whitman: The Expatriate's Dream of Home," American Studies 18 (Fall 1982), 47. He also notes the presence in that circle of Whitman biographer Oscar Lovell Triggs and also C. R. Ashbee, an early critic of both Whitman and Wright. Triggs was a friend of Sullivan and Wright.

50 Edward Carpenter, The Art of Creation, 3rd ed. (London: Allen, 1912), 231. See Religious Ecstasy, ed. Nils G. Holm (Stockholm: Almqvist, 1982), for some recent neurological and psychological findings on the subject.

51 I am thinking especially of Thomas Weiskel's The Romantic Sublime: Studies in the Structure and Psychology of Transcendence (Baltimore: Johns Hopkins University Press, 1976). 
"Vistas," $P W, 2: 404-405$.

53 "Vistas", $P W, 2: 404$.

54 See Lee Schlesinger, "Toward Infinite Expanse: The Use of Spatial Imagery in Nineteenth and Twentieth Century Poetry: A Phenomenological Study," Ph.D. Disertation, Yale University, 1973, 13.

55 See Henry Nash Smith, Virgin Land, ch. 9. Erastus Beadle was a Buffalo publisher who moved to New York City in 1860 to begin a weekly series of mass-market Westerns.

56 Whitman, "Song of the Open Road" 5:53-59, as cited by Wright, The Architectural Forum, January 1938.

57 Wright, An Autobiography, 3rd (expanded) ed. (New York: Horizon, 1977), 23.

58 Alan Gussow, A Sense of Place: The Artist and the American Land (San Francisco: Friends of the Earth, 1971), 27.

59 Whitman, Leaves, 548.

60 Wright, $A$ Testament (New York: Horizon, 1957), 219.

61 Lewis Mumford, "The Social Background of Frank Lloyd Wright," The Work of Frank Lloyd Wright, ed. Olgivanna Lloyd Wright (New York: Horizon, 1965), 74.

62 Wright, Autobiography, 45.

63 Wright, Autobiography, 67-68.

64 Arthur Schopenhauer, The World as Will and Idea (London: 1886), 1:454.

65 Leo Marx, The Machine in the Garden (New York: Oxford University Press, 1964), 26.

66 See Twombly, 185.

67 Twombly, 186, 188.

68 Wright, An Autobiography, 617; see also Wright, The Living City, 49, and Twombly, 228.

69 Wright, The Living City, 49 (and elsewhere).

70 One of the main themes of current investigations into Wright, as apparent in the Columbia University Symposium on Fallingwater of November 1986.

71 Wright, Testament, 130.

72 Wright, The Disappearing City (New York: Payson, 1932), 25.

73 Wright, The Disappearing City, 21.

74 Alfred North Whitehead, Process and Reality: An Essay in Cosmology (New York: Macmillan, 1929), 129.

75 Whitman, “Blue Ontario's Shore” 8:119, 122-124, 9:128-129; Leaves, 346. 